$\$=-$ 䔔

\title{
Assessment of ground water quality of lahar block, Bhind district in Madhya Pradesh
}

\author{
Shashi Kant ${ }^{1}$, Y.V. Singh ${ }^{1 *}$, Lokesh Kumar Jat ${ }^{1}$, R. Meena ${ }^{1}$ and S.N. Singh ${ }^{2}$ \\ ${ }^{1}$ Department of Soil Science and Agricultural Chemistry, Institute of Agricultural Sciences, \\ Banaras Hindu University, Varanasi-221 005, Uttar Pradesh \\ ${ }^{2}$ Krishi VighyanKendra, Institute of Agricultural Sciences, Banaras Hindu University RGSC, Barkccha, \\ Mirzapur -231 001,Uttar Pradesh \\ *Corresponding author E-mail:yvsingh59@rediffmail.com
}

\begin{abstract}
In sustainable groundwater study, it is necessary to assess the quality of groundwater in terms of irrigation purposes. The present study attempts to assess the groundwater quality through Irrigation Water Quality Index (IWQI) in hard-rock aquifer system and sustainable water use in Lahar block, Bhind of district, Madhya Pradesh, India. The quality of ground water in major part of the study area is generally good. In order to understand the shallow groundwater quality, the water samples were collected from 40 tube wells irrigation water. The primary physical and chemical parameters like potential Hydrogen $(\mathrm{pH})$, Total Dissolved Solids (TDS), calcium $\left(\mathrm{Ca}^{2+}\right)$, magnesium $\left(\mathrm{Mg}^{2+}\right)$, sodium $\left(\mathrm{Na}^{+}\right)$, potassium $\left(\mathrm{K}^{+}\right)$, bicarbonate $\left(\mathrm{HCO}_{3}^{-}\right)$, carbonate $\left(\mathrm{CO}_{3}^{2-}\right)$, chloride $\left(\mathrm{Cl}^{-}\right)$, and nitrate $\left(\mathrm{NO}_{3}^{-}\right)$were analyzed for (irrigation water quality index ) IWQI. The secondary parameters of irrigation groundwater quality indices such as Sodium Adsorption Ratio (SAR), Sodium Soluble Percentage (SSP), Residual Sodium Carbonate (RSC), Permeability Index (PI), and Kellies Ratio (KR) were also derived from the primary parameter for irrigation water quality index (IWQI). The IWQI was classified into excellent to unfit condition of groundwater quality based on their Water Quality Index (WQI). The IWQI $(82.5 \%+15.0 \%)$ indicate that slightly unsustainable to good quality of ground water. Due to this quality deterioration of shallow aquifer, an immediate attestation requires for sustainable development.
\end{abstract}

Keywords: Groundwater Quality; Irrigation Water Quality Indices; Permeability Index and Arrange Kallies Ratio etc.

\section{Introduction}

Groundwater is considered as the major source of usable water, so that quality of water is the main key factor in management of groundwater in a sustainable manner. In the past few decades, reports of ground water contamination have increased public concern about ground water quality (Yanggen and Born, 1990). Since groundwater is the primary source of water for domestic, agricultural and industrial uses in many countries and its contamination has been recognized as one of the most serious problems in India. Due to rapid growth of population, urbanization, industrialization and agriculture activities, ground water quality is depleted; it is also influenced by a contribution from the atmosphere and surface water bodies.

Approximately $70 \%$ of freshwater is consumed by agriculture. (Baroni et al., 2007). Fresh water is a finite resource, essential for agriculture, industry and even human existence, without fresh water of adequate quantity and quality; sustainable development will not be possible. The ground water resources are being utilized for drinking, irrigation and industrial purposes. Ground water contains a wide variety of dissolved inorganic chemical constituents in various concentrations, resulting from chemical and biochemical interactions between water and the geological materials. Inorganic contaminants, including salinity, chloride, nitrate, iron and arsenic are important in determining the suitability of ground water for irrigation and drinking purposes.
Quality of water is an important consideration in any appraisal of salinity or alkali conditions in an irrigated area. All irrigation water contains some salts, but the concentration and nature of salts vary. The quality of irrigation water depends primarily on the total amount of salt present and the proportion of $\mathrm{Na}^{+}$to other cation and certain other parameters. Rajankar et al. (2009) calculated WQI for different groundwater sources, viz., dug wells, bore wells, and tube wells at Khaperkheda Region, Maharashtra. The problems of water quality are more acute in areas that are densely populated thickly industrialized and have shallow water set (Shivran et al. 2006). Keeping view above facts, present study is undertaken to assess the shallow groundwater quality of Lahar block in Bhind district, Madhya Pradesh for irrigation purposes through different ground water quality indices and generate WQI.

\section{Study area}

Bhind district is situated in the northern part of the Madhya Pradesh and covers an area of about 4459 sq. $\mathrm{km}$. It lies between $\mathrm{N}$ Latitude $25^{\circ} 55^{\prime}$ and $26^{\circ} 45^{\prime}$ and E longitude $78^{\circ} 12^{\prime}$ and $79^{\circ} 05^{\prime}$. It is bounded in the North and east by Uttar Pradesh, in the south by the Gwalior and Datia districts in the west by the district Datia. Bhind district is divided into seven tehsils and six blocks. Lahar tehsil is one of the seven tehsil of Bhind district, Madhya Pradesh India. It is located in the east-southern area of the district. 


\section{Materials and method}

Groundwater quality data and World Health Organization (WHO) water quality standards were utilized in the present study. Sampling was carried out during pre-monsoon season (April) for the year 2015. Total 40 water samples were collected from the selected locations throughout the study area. Water quality secondary parameters name SAR, RSC, SSP; KR and PI were analyzed for IWQI. The statistical analysis of various quality parameters IWQI was classified into excellent to unfit condition of groundwater quality based on their Water Quality Index (WQI). Based on their severity of WQI the sub-basin further classified into good to pour good state of groundwater quality for sustainable development The physio-chemical analysis was performed following standard methods (APHA, 1992). The brief details of analytical methods and equipment used in the study are given in Table 1. Electrical conductivity and $\mathrm{pH}$ were measured using $\mathrm{EC}$ and $\mathrm{pH}$ meters. Total dissolved solids were estimated by ionic calculation method. $\mathrm{CO}_{3}{ }^{2-}$ and $\mathrm{HCO}_{3}{ }^{-}$were estimated by titrating with concentration $\mathrm{H}_{2} \mathrm{SO}_{4} \cdot \mathrm{Ca}^{2+}+\mathrm{Mg}^{2+}$ were analyses titrimetrically using standard EDTA. $\mathrm{Na}^{+}$and $\mathrm{K}^{+}$were measured by a flame photometer. $\mathrm{Cl}^{-}$was estimated by standard $\mathrm{AgNO}_{3}$ titration. Nitrate was estimated by using an ion selective electrode with $720 \mathrm{pH} / \mathrm{ISE}$ meter.

Table 1: Methods of Physico-Chemical Analysis of Water and Equipment Used in the Study (APHA, 1992)

\begin{tabular}{|c|c|c|c|}
\hline S.N. & Parameters & Method followed & Equipment \\
\hline 1 & $\mathrm{pH}$ & Electrometric & $\mathrm{pH}$ Meter \\
\hline 2 & Conductivity & Electrometric & $\begin{array}{l}\text { Conductivity Me- } \\
\text { ter }\end{array}$ \\
\hline 3 & Chloride & $\begin{array}{l}\text { Titration by } \mathrm{AgNO}_{3} \\
(0.01 \mathrm{~N})\end{array}$ & Titration \\
\hline 4 & Nitrate & $\begin{array}{l}\text { Direct ion selective elec- } \\
\text { trode }\end{array}$ & Electrochemically \\
\hline 5 & Sodium & $\begin{array}{l}\text { Flame emission spectros- } \\
\text { copy }\end{array}$ & Flame photometer \\
\hline 6 & Potassium & $\begin{array}{l}\text { Flame emission spectros- } \\
\text { copy }\end{array}$ & Flame photometer \\
\hline 7 & $\mathrm{Ca}^{2+}+\mathrm{Mg}^{2+}$ & $\begin{array}{l}\text { Titration by EDTA ( } 0.01 \\
\mathrm{~N})\end{array}$ & Titration \\
\hline 8 & $\begin{array}{l}\mathrm{CO}_{3}^{--} \text {! } \\
\mathrm{HCO}_{3}^{-}\end{array}$ & $\begin{array}{l}\text { Titration by Std. } \mathrm{H}_{2} \mathrm{SO}_{4} \\
(0.01 \mathrm{~N})\end{array}$ & Titration \\
\hline 9 & SAR & Calculation & - \\
\hline 10 & $\mathrm{RSC}$ & Calculation & - \\
\hline 11 & $\mathrm{KR}$ & Calculation & - \\
\hline 12 & SSP & Calculation & - \\
\hline 13 & PI & Calculation & - \\
\hline
\end{tabular}

\section{Irrigation water quality indices (IWQI)}

The various irrigation water quality indices were derived from the primary parameter of drinking water quality.

\section{i) Sodium adsorption ratio (SAR)}

SAR is an important parameter for determining the suitability of ground water for irrigation because it is a measure of alkali/sodium hazard to crops. SAR is calculated using the following formula where the concentration of all ions is in meq $\mathrm{L}^{-1}$.

$$
\mathrm{SAR}=\frac{\mathrm{Na}+}{\sqrt{\frac{\mathrm{Ca} 2++\mathrm{Mg} 2+}{2}}}
$$

\section{ii) Soluble sodium percentage (SSP)}

Wilcox (1955) has proposed classification scheme for rating irrigation water on the basis of soluble sodium percentage (SSP). The SSP was calculated by using following formula where the concentration of all ions is in meq $\mathrm{L}^{-1}$.

$$
\mathrm{SSP}=\frac{\mathrm{Na} \times 100}{\mathrm{Ca}+\mathrm{Mg}+\mathrm{Na}}
$$

The values of SSP less than 50 indicate good quality of water and higher values (i.e.>50) show that the water is unsafe for irrigation (USDA, 1954).

\section{iii) Residual sodium carbonate (RSC)}

Water containing carbonate plus bicarbonate concentration greater than the calcium plus magnesium concentration, referred as "residual sodium carbonate" and calculated as (Raghunath, 1987).

$\mathrm{RSC}=\left(\mathrm{CO}_{3}+\mathrm{HCO}_{3}\right)-(\mathrm{Ca}+\mathrm{Mg})$

\section{iv) Permeability index (PI)}

Permeability index is calculated by using the following formula:

$$
\mathrm{PI}=\frac{\mathrm{Na}+\sqrt{\mathrm{HCO}} 3}{\mathrm{Ca}+\mathrm{Mg}+\mathrm{Na}} \times 100
$$

Where, all the values are in $\mathrm{meq}^{-1}$. The PI values $>75$ indicate excellent quality of water for irrigation. If the PI values fall in between 25 and 75, they indicate good quality of water for irrigation. However, if the PI values are $<25$, they reflect unsuitable nature of water for irrigation.

v) Kelly's ratio (KR)

Kelly's ratio was calculated by using the following expression

$$
\mathrm{KR}=\frac{\mathrm{Na}+}{\mathrm{Ca} 2++\mathrm{Mg} 2+}
$$

Where, concentrations are expressed in meq $\mathrm{L}^{-1}$. The Kelly's ratio of unity or less than one is indicative of good quality of water for irrigation where as above one is suggestive of unsuitability for agricultural purpose due to alkali hazards (Karanth, 1987).

\section{vi) Corrosively ratio index (CRI)}

The magnitude of the corrosiveness of water can be assessed by using a perimeter known as corrositivity ratio Index (CRI), which can be determined by using the following formula.

$\mathrm{CR}=\frac{\frac{\mathrm{Cl}}{25.5+2 \mathrm{so} 4}}{2\left(\mathrm{CO} 2+\frac{\mathrm{HCO} 3}{100}\right)}$

The water having the corrositivity ratio less than one is safe and non corrosive. Corrositivity ratio greater than two is suggestive of corrosiveness.

\section{vii) Magnesium adsorption ratio (MAR)}

The Magnesium Adsorption Ratio (MAR) was calculated using the following equation (Raghunath, 1987):

$\mathrm{MAR}=\frac{\mathrm{Mg} \times 100}{\mathrm{Mg}+\mathrm{Ca}}$

Where, all the ionic constituents are expressed in meq $\mathrm{L}^{-1}$.

\section{Results and discussions}

Water quality is good and suitable for irrigation every crop. Irrigation water quality analysis is important in understanding current water quality and to making more informed decisions. Irrigation water testing provides regarding minerals present in water. Lahar block is one of the developing block in Bhind, district of Madhya Pradesh. The observed over all $\mathrm{pH}$ values ranging between 7.4 to 8.1 (Table 1) in different water sampling condition in which they are taken and $100 \%$ water sample suitable for irrigation which was within maximum permissible limit. EC values ranging from 0.33 to $1.65 \mathrm{dSm}^{-1}$ in the reported. TDS range from 211 to $1056 \mathrm{mg} \mathrm{L}^{-}$ 1. $\mathrm{NO}_{3}^{-}$values ranged between 0.01 to $210.6 \mathrm{mg} \mathrm{L}^{-1}$. Chloride ranges from 1.90 to $15.30 \mathrm{meq} \mathrm{L}^{-1}$. Carbonate and bicarbonate 
range from 0.0 to 1.1 and 2.10 to $8.30 \mathrm{meq}^{-1}$. Potassium value ranged 0.00 to 0.70 meq $\mathrm{L}^{-1}$. Sodium values ranged between 1.50 to 42.70 meq $\mathrm{L}^{-1}$. Calcium plus magnesium recorded between 2.5 to $32.0 \mathrm{meq} \mathrm{L}^{-1}$. The rock water interaction and aquifer material played major role in evolution of water chemistry, which was further influenced by the evaporation process. Geological location is one of the most important factors affecting ground water quality (Becket et al., 1985). The calculated value of SAR in the study area has been shown about $82.50 \%$ of area under suitable. The $17.50 \%$ of study areas fall under high to very high SAR for irrigation. When SAR values are greater than 18 , irrigation water will cause permeability problems on shrinking and swelling in clay soil (Saleh et al., 1999). The higher the SAR values in the water, the greater the risk of $\mathrm{Na}$ which leads to the development of an alkaline soil (Todd, 1980), while a high salt concentration in water leads to formation of saline soil. The average Sodium Absorption Ratio (SAR) of ground water in the study area range is 0.87 $26.22 \mathrm{meq} \mathrm{L}^{-1}$. In ground water sodium absorption ratio becomes $>18-26 \mathrm{ppm}$, it is called exchangeable sodium percentage. In the study area, RSC varies between $-28.2 \mathrm{ppm}$ to $5.1 \mathrm{ppm}$. Hazards from RSC are low to medium and only at two locations RSC are in the high hazard category. Where, the concentrations of ions are expressed in meq $\mathrm{L}^{-1}$. The values of SSP less than 50 indicate good quality of water and higher values (i.e. > 50) show that the water is unsafe for irrigation (USDA, 1954). It is observed from (Table1) that, majority of the groundwater samples have SSP values greater than 50 , which can be graded as unsuitable for irrigation. On the basis of PI, the groundwater in the study area can be classified as good (67\%) for agricultural use. Most of the groundwater sample in the study area falls in the corrosively ratio index zone less than 1 and so they are safe, suitable and less corrosive and hence can be used for domestic or industrial purposes. The corrositivity of the groundwater in the study area ranges between 0.14 and 8.05. Where, concentrations are expressed in meq $\mathrm{L}^{-1}$. The Kelly's ratio of unity or less than one is indicative of good quality of water for irrigation whereas above one is suggestive of unsuitability for agricultural purpose due to alkali hazards (Karanth, 1987). It is observed from (Table 1), the majority of the samples in the study area fall more than one. This suggests that, the samples from study area are unsuitable for irrigation.

Table 2: Cations and Anions in Ground Water of Lahar Block in Bhind District

\begin{tabular}{lcccc} 
District & & Mean & S.D. \pm & C.V. $(\%)$ \\
\hline Water characteristics & Range & 7.75 & 0.18 & 2.36 \\
$\mathrm{pH}$ & $7.40-8.10$ & 0.82 & 0.38 & 46.29 \\
$\mathrm{EC}$ & $211.00-1.65$ & 546.05 & 239.35 & 43.83 \\
$\mathrm{TDS}$ & $0.01-210.60$ & 16.72 & 41.59 & 248.77 \\
$\mathrm{NO}_{3}^{-}\left(\mathrm{meq} \mathrm{L}^{-1}\right)$ & $1.90-15.30$ & 4.92 & 2.95 & 59.97 \\
$\mathrm{Cl}^{-}\left(\mathrm{meq} \mathrm{L}^{-1}\right)$ & $0.00-1.10$ & 0.36 & 0.33 & 90.24 \\
$\mathrm{CO}_{3}^{2-}\left(\mathrm{meq} \mathrm{L}^{-1}\right)$ & $2.10-8.30$ & 4.44 & 1.47 & 33.04 \\
$\mathrm{HCO}_{3}^{-}\left(\mathrm{meq} \mathrm{L}^{-1}\right)$ & $0.00-0.70$ & 0.08 & 0.12 & 141.43 \\
$\mathrm{~K}^{+}\left(\mathrm{mg} \mathrm{L}^{-1}\right)$ & $1.50-42.70$ & 10.89 & 8.50 & 78.10 \\
$\left.\mathrm{Na}^{2} \mathrm{mg} \mathrm{L}^{-1}\right)$ & $2.50-32.00$ & 7.37 & 5.16 & 70.06 \\
$\mathrm{Ca}^{2+} \mathrm{Mg}^{2+}\left(\mathrm{mgL}^{-1}\right)$ & & & & \\
\hline
\end{tabular}

In order to assess the irrigation water quality in Lahar block of Bhind district Madhya Pradesh. An attempt has been made to develop a model on Irrigation Water Quality Index (IWQI). The various irrigation water quality indices such as SAR, SSP, RSC, $\mathrm{PI}$, and KR were considered to assess the ground water quality for irrigation. The indices value summed, then classified into excellent to unfit ground-water quality (Table 4). The output has shown only $82.50 \%$ of water slightly unsustainable for irrigation, whereas some parts of the area (15\%) good quality found in water sample and only $2.50 \%$ found in very poor quality these findings are in close conformity with those reports by (Anbazaghan, 2014).
Table3: Water Quality Classification Based on Water Quality Index Value

\begin{tabular}{|c|c|c|c|c|c|c|c|c|}
\hline $\begin{array}{l}\text { Sample } \\
\text { No. }\end{array}$ & SAR & RSC & KR & SSP & PI & MAR & CR & IWQI \\
\hline $\mathrm{w}_{1}$ & 5.40 & -5.1 & 1.28 & 56.25 & 15.11 & 36.2 & 0.8 & 110.03 \\
\hline $\mathrm{w}_{2}$ & 6.11 & -1.6 & 1.96 & 66.32 & 17.15 & 32.9 & 1.2 & 124.04 \\
\hline$w_{3}$ & 1.57 & -6.5 & 0.36 & 26.82 & 16.24 & 29.7 & 1.6 & 69.79 \\
\hline $\mathrm{W}_{4}$ & 7.67 & -1.2 & 2.12 & 67.97 & 09.62 & 41.1 & 1.8 & 129.08 \\
\hline $\mathrm{w}_{5}$ & 4.86 & 0.5 & 1.55 & 60.80 & 23.89 & 23.5 & 3.2 & 118.3 \\
\hline $\mathrm{w}_{6}$ & 4.62 & -1.8 & 1.33 & 57.14 & 52.22 & 28.6 & 2.6 & 144.71 \\
\hline$w_{7}$ & 12.3 & 0.7 & 3.32 & 77.69 & 18.55 & 31.8 & 2.7 & 147.05 \\
\hline $\mathrm{w}_{8}$ & 4.74 & -4.0 & 1.30 & 56.66 & 17.01 & 33.5 & 3.1 & 112.31 \\
\hline $\mathrm{w}_{9}$ & 2.46 & -2.1 & 0.68 & 40.74 & 41.10 & 51.8 & 1.9 & 136.58 \\
\hline $\mathrm{w}_{10}$ & 11.7 & -0.7 & 3.88 & 79.54 & 45.78 & 57.8 & 2.4 & 200.37 \\
\hline $\mathrm{w}_{11}$ & 11.2 & 0.1 & 3.31 & 76.82 & 38.20 & 48.6 & 2.9 & 181.11 \\
\hline $\mathrm{w}_{12}$ & 9.26 & -2.3 & 2.24 & 69.15 & 34.89 & 44.5 & 2.7 & 160.44 \\
\hline $\mathrm{w}_{13}$ & 4.24 & -7.6 & 0.86 & 46.42 & 43.15 & 36.5 & 4.1 & 91.17 \\
\hline $\mathrm{w}_{14}$ & 1.15 & -28.2 & 0.14 & 12.56 & 31.18 & 32.1 & 4.5 & 53.43 \\
\hline $\mathrm{w}_{15}$ & 1.30 & -17.6 & 0.20 & 16.66 & 27.00 & 32.8 & 4.9 & 65.26 \\
\hline $\mathrm{w}_{16}$ & 2.70 & -5.0 & 0.56 & 36.11 & 21.63 & 38.5 & 4.7 & 99.20 \\
\hline $\mathrm{w}_{17}$ & 1.86 & -1.0 & 1.11 & 52.75 & 27.10 & 26.4 & 5.4 & 113.62 \\
\hline $\mathrm{w}_{18}$ & 5.03 & -3.5 & 1.34 & 57.31 & 30.51 & 24.9 & 5.6 & 121.19 \\
\hline $\mathrm{w}_{19}$ & 7.16 & 0.9 & 2.25 & 71.42 & 18.88 & 28.1 & 5.7 & 134.41 \\
\hline $\mathrm{w}_{20}$ & 2.76 & 0.6 & 0.91 & 47.72 & 18.05 & 25.9 & 5.8 & 101.74 \\
\hline $\mathrm{w}_{21}$ & 4.66 & -3.3 & 1.12 & 52.97 & 13.18 & 52.8 & 6.1 & 127.53 \\
\hline $\mathrm{w}_{22}$ & 2.45 & -7.4 & 0.46 & 31.70 & 19.88 & 54.6 & 6.4 & 108.09 \\
\hline $\mathrm{w}_{23}$ & 5.47 & -2.5 & 1.53 & 60.48 & 29.24 & 51.7 & 6.8 & 152.72 \\
\hline $\mathrm{w}_{24}$ & 3.22 & 0.1 & 1.12 & 52.94 & 12.92 & 49.6 & 6.3 & 126.20 \\
\hline $\mathrm{w}_{25}$ & 5.46 & 1.2 & 2.44 & 70.93 & 23.65 & 45.6 & 0.9 & 150.18 \\
\hline $\mathrm{w}_{26}$ & 0.87 & 1.8 & 0.25 & 20.00 & 15.83 & 42.2 & 1.2 & 82.15 \\
\hline $\mathrm{w}_{27}$ & 4.12 & -4.0 & 1.09 & 52.34 & 13.91 & 47.1 & 1.8 & 116.36 \\
\hline $\mathrm{w}_{28}$ & 3.51 & -1.7 & 1.72 & 47.55 & 14.29 & 46.5 & 1.4 & 113.27 \\
\hline $\mathrm{w}_{29}$ & 4.89 & 0.3 & 1.14 & 63.30 & 10.44 & 38.5 & 7.1 & 125.67 \\
\hline $\mathrm{w}_{30}$ & 3.59 & 0.3 & 6.90 & 53.13 & 64.12 & 34.3 & 7.4 & 169.74 \\
\hline $\mathrm{w}_{31}$ & 21.82 & -0.8 & 8.05 & 87.34 & 08.50 & 36.8 & 7.6 & 169.31 \\
\hline $\mathrm{w}_{32}$ & 26.22 & 0.0 & 2.28 & 88.95 & 24.53 & 33.6 & 7.5 & 183.08 \\
\hline $\mathrm{w}_{33}$ & 7.39 & -1.8 & 2.98 & 69.54 & 33.22 & 24.5 & 0.9 & 136.73 \\
\hline $\mathrm{w}_{34}$ & 9.86 & 0.0 & 3.06 & 74.88 & 57.27 & 26.8 & 1.4 & 173.27 \\
\hline$w_{35}$ & 13.25 & -3.4 & 1.86 & 75.39 & 22.29 & 29.7 & 1.6 & 140.69 \\
\hline $\mathrm{w}_{36}$ & 6.40 & -2.5 & 0.97 & 65.08 & 09.59 & 28.6 & 1.8 & 109.94 \\
\hline$w_{37}$ & 3.00 & -0.2 & 1.67 & 49.46 & 11.76 & 35.4 & 3.2 & 104.29 \\
\hline $\mathrm{w}_{38}$ & 4.79 & 1.4 & 1.88 & 62.60 & 19.22 & 31.8 & 3.6 & 125.29 \\
\hline $\mathrm{w}_{39}$ & 5.92 & -0.2 & 1.25 & 65.27 & 08.90 & 33.4 & 3.5 & 118.04 \\
\hline $\mathrm{W}_{40}$ & 3.16 & 5.1 & 2.54 & 55.55 & 16.22 & 32.5 & 2.8 & 117.87 \\
\hline Mean & 6.2 & $\begin{array}{l}-2 \\
.58\end{array}$ & 1.88 & 56.91 & 24.41 & 37.04 & 3.67 & 126.61 \\
\hline Range & $\begin{array}{l}0.87- \\
26.22\end{array}$ & $\begin{array}{l}-28.2- \\
5.10\end{array}$ & $\begin{array}{l}0.14- \\
8.05\end{array}$ & $\begin{array}{l}12.56 \\
-88.95\end{array}$ & $\begin{array}{l}8.50- \\
64 . \\
12\end{array}$ & $\begin{array}{l}23.50- \\
57.80\end{array}$ & $\begin{array}{l}0.80- \\
7.60\end{array}$ & $53.43-200.37$ \\
\hline $\mathrm{SD} \pm$ & 5.19 & 5.51 & 1.59 & 18.07 & $\begin{array}{l}13 \\
.72\end{array}$ & 9.49 & 2.15 & 32.15 \\
\hline $\begin{array}{l}\text { CV } \\
(\%)\end{array}$ & 83.63 & $\begin{array}{l}-214 \\
.05\end{array}$ & 84.95 & 31.75 & 56.21 & 25.62 & $\begin{array}{l}58 \\
.46\end{array}$ & 25.39 \\
\hline
\end{tabular}

Note- SAR=Sodium adsorption ratio $\mathrm{RSC}=$ Residual sodium carbonate $\mathrm{KR}=\mathrm{Kelly}, \mathrm{S}$ ratio

$\mathrm{SSP}=$ Soluble sodium percentage $\mathrm{PI}=$ Permeability index MAR= Magnesium adsorption ratio $\mathrm{CR}=$ corrosively ratio $\mathrm{IWQI}=$ Irrigation water qwality index.

Table 4: Water Quality Classification Based on WQI Value

\begin{tabular}{|c|c|c|c|c|}
\hline $\begin{array}{l}\text { Water } \\
\text { value } \\
\text { range }\end{array}$ & $\begin{array}{l}\text { Water } \\
\text { quality }\end{array}$ & $\begin{array}{l}\text { No. of } \\
\text { samples } \\
\text { (IWQI) }\end{array}$ & (\%) & Sustainable state \\
\hline$<50$ & Excellent & 0 & 0 & Sustainable \\
\hline $51-100$ & Good & 6 & 15 & Sustainable \\
\hline $101-200$ & Poor & 33 & 82.50 & $\begin{array}{l}\text { Slightly Unsus- } \\
\text { tainable }\end{array}$ \\
\hline $201-300$ & Very poor & 1 & 2.50 & Unsustainable \\
\hline$>301$ & Very bad & Nil & Nil & $\begin{array}{l}\text { Highly Unsus- } \\
\text { tainable }\end{array}$ \\
\hline
\end{tabular}

Correlation between water quality parameters

In the ground water, $\mathrm{pH}$ shows significant positive correlation with $\mathrm{CO}_{3}{ }^{2-}\left(\mathrm{r}=0.324^{*}\right)$ and non-significant negative correlation with $\mathrm{EC}(\mathrm{r}=-0.098), \mathrm{NO}_{3}{ }^{-}(\mathrm{r}=-0.082), \mathrm{K}^{+}(\mathrm{r}=-0.121)$ and $\mathrm{Cl}^{-}(\mathrm{r}=-$ 0.259). Reported by have also similar result that Khanna (2012) $\mathrm{pH}$ significant correlated carbonate $(\mathrm{r}=0.336)$.

In the ground water, EC shows negatively significant correlation with TDS $\left(\mathrm{r}=0.512^{* *)}\right.$ and non-significant positive correlation with $\mathrm{NO}_{3}{ }^{-}(\mathrm{r}=0.220)$ and TDS ( $\left.\mathrm{r}=0.151\right)$ Yadav, R.K. (2012) Ground 
Water have also reported the similar result in of Jaipur City (Rajasthan, India)

SAR shows significant negative correlation with $\mathrm{Cl}^{-}\left(\mathrm{r}=-0.362^{*}\right)$ and $\mathrm{Ca}+\mathrm{Mg}^{2+}\left(\mathrm{r}=-0.972^{* * *}\right)$ and non-significant negative correlation with $\mathrm{NO}_{3}^{-}, \mathrm{K}^{+}$, and TDS in ground water. In addition to the RSC, the excess sum of carbonate and bicarbonate in ground water over the sum of calcium and magnesium also influences the suitability of ground water for irrigation. Continued usage of high residual sodium carbonate water affects the yields of crops. RSC shows significant negative correlation with $\mathrm{Cl}^{-}\left(\mathrm{r}=-0.362^{*}\right)$ and $\mathrm{Ca}^{2+}+\mathrm{Mg}^{2+}\left(\mathrm{r}=-0.972^{* * *}\right)$ and non-significant negative correlation with $\mathrm{NO}_{3}^{-}, \mathrm{K}^{+}$, and TDS in the ground water. Yadav K. K., (2011) similar result given in Agra city.

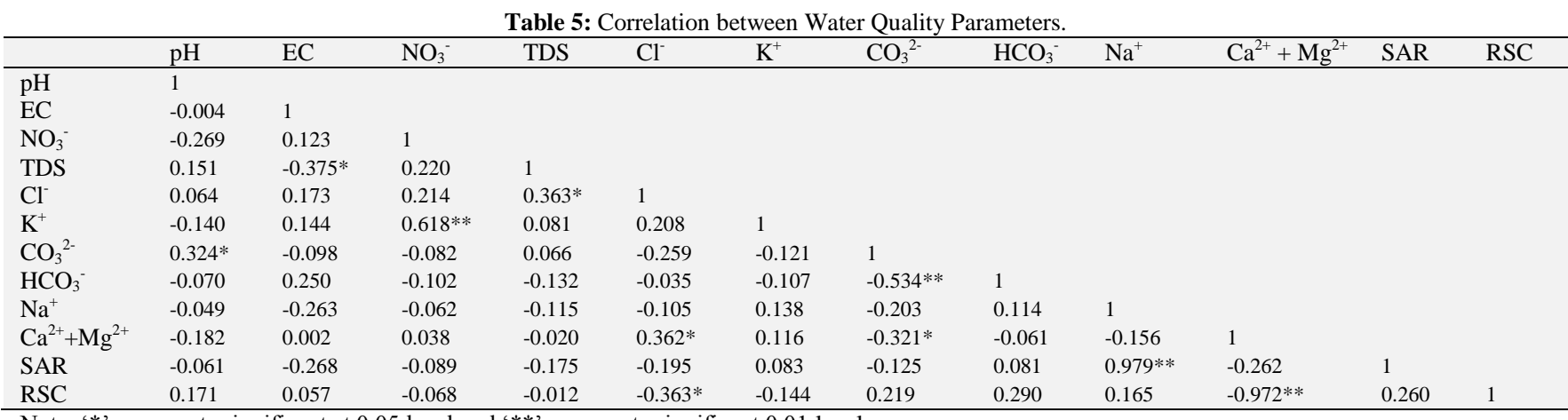

Note: '*' represents significant at 0.05 level and ' $* *$ ' represents significant 0.01 level.

\section{Conclusion}

In the ground water, $\mathrm{pH}$ shows significant positive correlation with $\mathrm{CO}_{3}{ }^{2-}\left(\mathrm{r}=0.324^{*}\right)$.In the ground water, EC shows negatively significant correlation with TDS $\left(\mathrm{r}=1.00^{* * *}\right)$ and non-significant positive correlation with $\mathrm{NO}_{3}{ }^{-}(\mathrm{r}=0.220)$ and TDS ( $\left.\mathrm{r}=0.151\right)$. SAR shows significant negative correlation with $\mathrm{Cl}^{-}\left(\mathrm{r}=-0.362^{*}\right)$ and $\mathrm{Ca}$ $+\mathrm{Mg}^{2+}\left(\mathrm{r}=-0.972^{* *}\right)$. RSC shows significant negative correlation with $\mathrm{Cl}^{-}\left(\mathrm{r}=-0.362^{*}\right)$ and $\mathrm{Ca}^{2+}+\mathrm{Mg}^{2+}\left(\mathrm{r}=-0.972^{* *}\right)$ and nonsignificant negative correlation with $\mathrm{NO}_{3}{ }^{-}, \mathrm{K}^{+}$, and TDS in the ground water.

The present study may help to improve groundwater resource assessment management, achieves social, economic and environmental benefits to support governance and policy. The results have shown that the ground water of study area has been in good in IWQI and maximum samples $(82.5 \%)$ fall under slightly unsustainable for irrigation. This study can offer the requisite information for the authority to pursue the sustainable approaches on groundwater management and contamination prevention. As the poor quality of irrigation water of restricted for selection of the crops for study area, and only resistant crops can grow successfully. Therefore, it is strongly needed to improved irrigation practices and develops resistant varieties of crop that can grow without any yield loss in study area.

\section{Acknowledgement}

The authors thankful to Head, Department of Soil Science and Agricultural Chemistry, Institute of Agricultural Sciences, Banaras Hindu University to providing necessary facility for conducting this research work.

\section{References}

[1] Anbazhagan, S., Das, M.K., Balamurugan, G., (2014). Hydro geochemical studies in hard rock aquifer system, Hosur, India. Indian Journal of Geochemistry, 22 (2): 519-535.

[2] APHA (1992). Standard Methods for the Examination of Water and Waste Waters, American Public Health Association, 18th Edition, Washington, DC

[3] Becket W., Mohammed A. and Slanina P. (1985) Uptake of radiolabelled alpha-linoleic, arachidonic and oleic acid in tissues of norma and essential fatty acid-deficient rats-- an autoradiographic study. Annul of Nutrient Metab, 29, 65 75.http://dx.doi.org/10.1159/000176963.

[4] Baroni, L., Cenci, L. and M. Berati (2007). Evaluating the environmental impact of various dietary patterns combined with different food production systems. Europion Journal of Clinical Nutrients, 61: 279-286.http://dx.doi.org/10.1038/sj.ejcn.1602522.

[5] Karanth, K. R., (1987). Groundwater assessment, development and management, Tata-McGraw Hill Publishing Company Limited, New Delhi.

[6] Khanna, D.R., Bhutiani, R., Matta,G., Singh, V. and Ishaq, F. (2012). Seasonal variation in physico-chemical characteristic status of River Yamuna in Doon valley. Environment Conservation Journal, 13(1\&2): 125-128.

[7] Raghunath, I.M., (1987). Groundwater. 2nd Edn, Wiley Eastern Ltd., New Delhi, India.

[8] Rajankar, P.N., Gulhane, S.R. and Tambekar, D.H., (2009). Water quality assessment of groundwater resources in Nagpur region (India) based on WQI, E Journal of Chemistry, 6(3):905908.http://dx.doi.org/10.1155/2009/971242.

[9] Sivram (2006). Assessment of groundwater quality for drinking irrigation purposes: a case study of Peddavanka watershed, Anantapur District, Andhra Pradesh, India. Environmental Geology, 48:702-712.

[10]Saleh, A., Al-Ruwaih, F., Shehata, M., (1999). Hydrogeochemical processes operating within the main aquifers of Kuwait. Journal Arid Environmental, 42:195-209.http://dx.doi.org/10.1006/jare.1999.0511.

[11]Todd, DK (1980) Groundwater Hydrology. John Wiley and Sons Publication, Canada, 280-281.

[12]U.S. Department of Agriculture, (1954) U.S. Salinity Laboratory Staff, Diagnosis and Improvement of Saline and Alkali Soils. Handbook 60. Washington, D.C.

[13]Wilcox, L.V (1955), Classification and use of irrigation waters. U.S Dept. Agric. (Circ. 969, pp. 19).Washington, D.C.

[14] World Health Organisation (WHO), (2006). International Drinking Water Standards. Geneva, WHO.

[15] Yadav, S., Firdaus,T., Kumar, A, Alauddin, S. (2012) Spectrophotometric study of Iron, Nitrate and Phosphate in the River Gomti of Jaunpur City, International journal of Science Research, 1:6-11.

[16] Yanggen, D.A. and Born, S.M. 1990. Protecting groundwater quality by managing local land use. Journal of Soil Water Conservation, 45: 207-210.

[17] Yadav, K.K., 2012. Physico-chemical analysis of selected ground water samples of Agra city, India. Recent Research Science Technology, 4(11): 5154.

[18] Yadav,R.K.(2012) Correlation Of Physico-Chemical Analysis Of Ground Water Of Jaipur City (Rajasthan, India) International journal of Science and Nature, 3(4): 923-924. 